\title{
The Growth and Reproduction Characteristics of Neogobius melanostomus Populations in its Native Habitat of Lake Karaboğaz (Black Sea, Turkey)
}

\author{
Neogobius melanostomus'un Yerel Habitatı Olan Karaboğaz \\ Gölü'nde (Karadeniz, Türkiye) Yaşayan Populasyonunun Büyüme \\ ve Üreme Özellikleri
}

Research Article

Seda Macun

Hacettepe University, Faculty of Science, Department of Biology, Beytepe, Ankara, Turkey.

\begin{abstract}
A B S TR AC T
The age and size composition, growth rate and reproductive biology of the round goby, Neogobius melanostomus, were studied from 266 specimens from August 2011 to August 2012. The ages of $N$. melanostomus ranged from I to IV years, with age class II years dominant. The female: male ratio of the sample was found to be $0.62: 1$. The results indicated that the total value of the whole population size varied from $91 \mathrm{~mm}$ to $190 \mathrm{~mm}$ and the weight value varied from $12 \mathrm{~g}$ to $119 \mathrm{~g}$. The minimum and maximum total length for female and male were 100-166 mm and 91-190 mm, respectively. According to these results, it was determined that the growth values of N. melanostomus living in Lake Karaboğaz are significantly higher than Great Laurentian Lakes Basin, and lower than Baltic Sea populations. The sexual maturation age of N. melanostomus was year I for female and year II for male and the reproduction period of this species was in April - September. The highest number of eggs of N. melanostomus population living in Lake Karaboğaz was 2477 but it was determined to be lower than the expected values.
\end{abstract}

\section{Key Words}

Neogobius melanostomus, invasive species, growth, reproduction.

\section{öz}

\begin{abstract}
Neogobius melanostomus'un yaş ve boy ilişkileri, büyüme özellikleri ve üreme özelliklerinin araştırıldığı bu çalışma 266 türde, Ağustos 2011-Ağustos 2012 tarihleri arasında gerçekleştirilmiştir. Yapılan araştırma sonucunda yaş dağılımı I-IV arasında olmakla birlikte, baskın yaş sınıfı II'dir. Dişi:erkek oranı 0.62:1 olarak tespit edilmiştir. Tüm populasyonda toplam boy değerleri 91-190 mm arasında değişirken, ağırlık değerleri 12$119 \mathrm{~g}$ arasında değişmektedir. Toplam boy minimum ve maksimum değerleri dişilerde 100-166 mm, erkeklerde ise 91-190 mm arasındadır. Bu sonuçlara göre Karaboğaz Gölü'nde yaşayan N. melanostomus'un büyüme değerleri Great Laurentian Gölleri'nde sistemlerde yaşayan populasyonlardan daha yüksek, Baltık Denizi populasyonlarından ise daha düşüktür. N. melanostomus'un eşeysel olgunluk yaşı dişilerde I, erkeklerde ise Il olarak tespit edilmiştir. Ayrıca türün üreme dönemi nisan ve eylül ayları arasındadır. Karaboğaz Gölü'nde yaşayan N. melanostomus populasyonunun en yüksek yumurta sayısı 2477 olmakla birlikte beklenen değerlere göre düşük sayıda olduğu tespit edilmiştir.
\end{abstract}

\section{Anahtar Kelimeler}

Neogobius melanostomus, istilacı türler, büyüme, üreme.

Article History: Received: May 10, 2017; Revised: June 12, 2017; Accepted: Aug 10, 2017; Available Online: Dec 25, 2017. DOI: 10.15671/HJBC.2018.205

Correspondence to: S. Macun, Hacettepe University, Faculty of Science, Department of Biology, Beytepe, Ankara, Turkey. 


\section{INTRODUCTION}

N. melanostomus (Pallas, 1814) is a member of the Gobiidae family and a bottom-dwelling fish native to the Ponto-Caspian region [1]. $N$. melanostomus also occur in lower and middle reaches of rivers, but only in slightly brackish or freshwater [2]. During spring through fall in the Black Sea, round gobies are found in slow rivers, lagoons and brackish coastal water up to $20 \mathrm{~m}$, and migrate to inshore areas of the North Caspian region even while these areas are still partially frozen [3].

Ship ballast-water transport is considered to be the most probable human-mediated means by which the fish have been transferred and introduced to new locations [4]. The round goby has successfully invaded several European and North American water bodies including the Baltic Sea [5-9], Germany [10,11], Chicago [12,13], Canada [14], Atlantic [15], the Netherlands [16], Hungary [17], Russia [18], Lithuania [19]. Although N. melanostomus is a native species in the aquatic ecosystems of Turkey, its occurrence threatens other aquatic ecosystems. Having an important role in the invasion, many studies have been conducted and conferences and meetings have been organized about round goby [20]. Understanding life-history characteristics, such as growth, is vital for predicting the long-term effects of non-native species and developing practical management [21] along with long-term conservation techniques [22]. Despite several studies on the biology, ecology and natural history of $N$. melanostomus, there have not been any studies directly examining the growth and reproductive characteristics of the individual fish from the native habitat for the purpose of examining their natural history. Tarkan et al. (2006) investigated the length-weight relationships of $N$. melanostomus in the Sea of Marmara and Demirhan and Can (2007) studied them in the Black Sea $[23,24]$. Although these studies reported the length-weight relationships of the round goby, they were not able to give information on the seasonal growth and reproductivity of $N$. melanostomus. The present study aimed to determine the growth rate and breeding season of $N$. melanostomus in the native habitat (Figure 1).

\section{MATERIALS and METHODS}

\section{Study Site}

The Kizılırmak Delta is one of the biggest and most important wetlands located on the Black Sea coasts of Turkey. The whole delta is one of 13 Ramsar sites in Turkey. The Delta has been shown among the most important Bird Areas (IBA) of

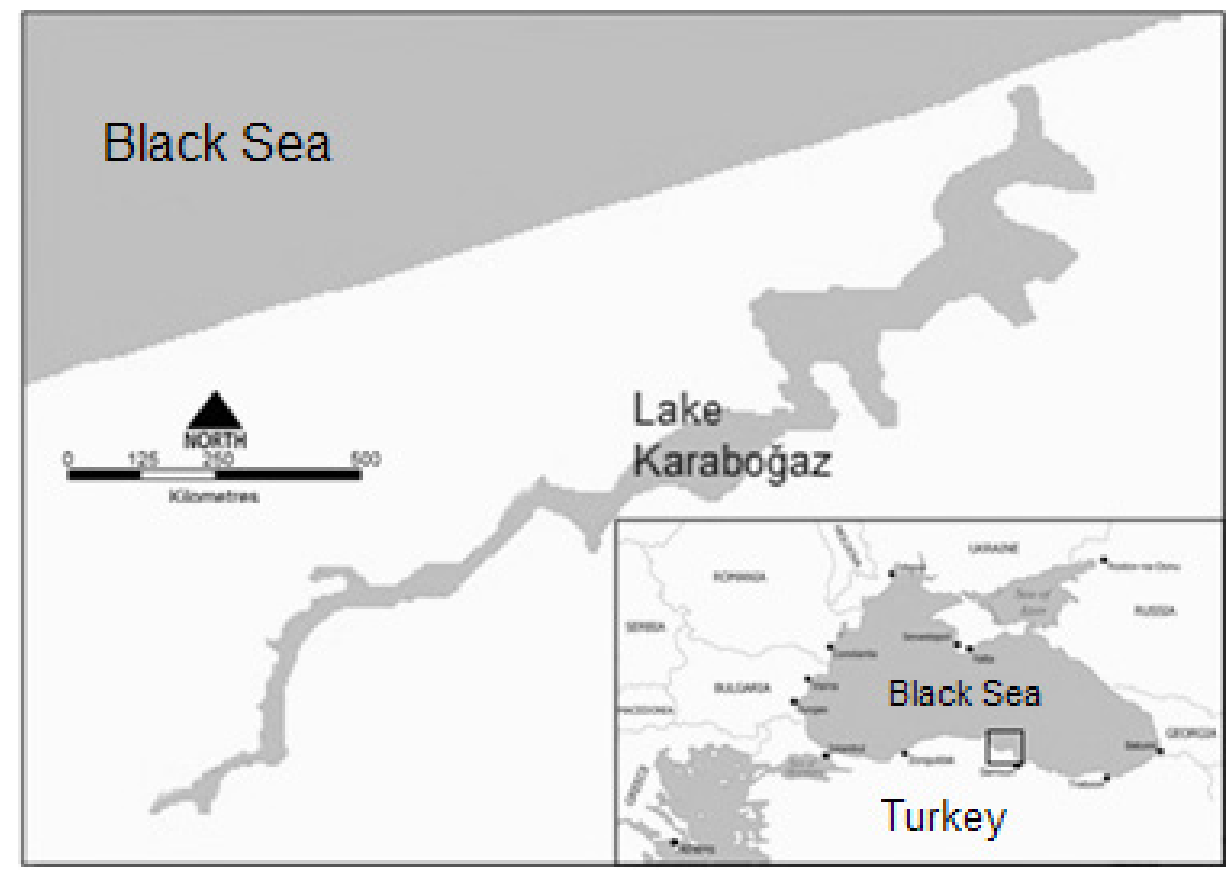

Figure 1. Lake Karaboğaz, the lagoon lake where the study was conducted, Turkey. 
Europe by BirdLife International. Lake Karaboğaz (north latitude $41^{\circ} 38^{\prime}$ and east longitude $35^{\circ} 38^{\prime}$ ), where the study was conducted, is a brackish water lagoon lake located $10 \mathrm{~km}$ west of the mouth of the Kızılırmak at sea level with the surface area of 1500 hectares. Lake Karaboğaz is the closest lake to the sea in the Kızılırmak Delta and connects to the Black Sea via a narrow sandy barrier located in its north-west region (Figure 1). The length of the lake is $6 \mathrm{~km}$ and the width is approximately 1 $\mathrm{km}$. Lake Karaboğaz is shallow like other lagoons in the delta and its deepest area is approximately 2.5 meters. It is characterized by brackish water due to the salt water entering from the north. The freshwater inflow is provided by small streams from the south to the lake (the Marda and Berdaş Streams).

In the monthly measurements made in Lake Karaboğaz between August 2011 and August 2012, the depth of the lake water was determined to be between $40-240 \mathrm{~cm}$. The water temperature varies between $6.1-26.7^{\circ} \mathrm{C}$ depending on the season. The dissolved oxygen values of the lake, of which light transmittance is between $25-160 \mathrm{~cm}$, vary between 2.4-13.9 mg/l. The salinity of Lake Karaboğaz, which is a lagoon lake, varies between 0.5-20.9. According to the data obtained, Lake Karaboğaz is in the mixooligohaline class in general.

\section{Sampling Methods}

The monthly sampling was performed in Lake Karaboğaz between August 2011 and August 2012 at 4 stations. The sampling could not be performed in January 2012 due to the unfavourable weather conditions. In the determination of the stations, the connection of the lake to the sea (1st station), the channels ( 2 nd and $3 r$ station) providing the freshwater inflow to the lake from residential areas and agricultural lands, and the mirror of the lake (4th station) were taken into consideration. The physical characteristics of the lake water such as the water temperature, depth, light transmittance, dissolved oxygen, electrical conductivity, salinity and $\mathrm{pH}$ were measured from the determined stations using YSI 556 MPS, Hydrobios Secchi Disc at the site.

Simple trammel nets with $17 \mathrm{~mm}$ mesh opening were used for fishing. The fish samples caught were placed in jars containing 4\% formaldehyde and brought to the laboratory. While the study of Lagler (1966) was used in the scale preparations prepared for the age determination, the studies of CraggHine and Jones (1969), Philipart (1972) and Thomas (1968) were used in the identification of age rings [25-28]. All individuals within the scope of the study were classified by age groups and sex. The sex of the samples was determined macroscopically by looking at the urogenital papilla in the ventral of individuals and by performing dissection [2].

\section{Data analysis}

All individuals caught during the study were classified by age and sex groups, and the Specific growth rate was calculated according to Wootton (1990): $G_{L}=\left(\log _{e} L_{T f} \cdot L_{T i}^{-1}\right) t^{-1}$ and $G_{w}=\left(\log _{e} W_{f} \cdot W_{i}{ }^{-1}\right) t^{-1}$, where $G_{L}$ is the length growth rate, $G_{w}$ is the weight growth rate, $L_{T f}$ is the final $L_{T}$ and $L_{W}$ is the final $W$, $\mathrm{L}_{\mathrm{Ti}}$ and $\mathrm{W}_{\mathrm{i}}$ are the initial $\mathrm{L}_{\mathrm{T}}$ and $W$ and $t$ is the time interval [29]. Fulton's condition factor $(K)$ was calculated monthly as $\mathrm{K}=10^{5} / \mathrm{L}_{\mathrm{t}} \mathrm{K}_{\mathrm{H}}=\mathrm{W} 10^{5} / \mathrm{L}^{3}{ }_{\mathrm{t}}$. The von Bertalanffy growth equation was estimated by $L_{t}=L_{\infty}\left[1-e^{-k(t-t 0}\right]$. The growth performance index was estimated by $\varnothing=\log _{10}(k)+2 \log _{10}\left(L_{\infty}\right)$ [29].

The gonads of female and male individuals were weighed at $0.01 \mathrm{mg}$ sensitivity for the determination of their reproduction period and calculation of the gonadosomatic index. The number of eggs was estimated by the Gravimetric Method using ovaries preserved in $4 \%$ formaldehyde. Furthermore, fecundity was calculated by using the Gravimetric Method [31]. In female individuals, the egg diameter was measured in 30 eggs taken from the head, middle and end part of the gonads. The fish egg diameters were calculated by taking the mean of the obtained values. The change of the gonadosomatic index (GSI) and egg diameter by months was taken as a basis for determining the reproduction period. The gonadosomatic index was calculated with the equation of $G S I=\left(G_{W} / W\right) \times 100$ [32].

\section{RESULTS}

\section{Age and Growth}

The age range of 266 samples obtained from Lake Karaboğaz was found to be between I and IV in both male and female individuals. The total length and weight values by sex are presented in Table 1 . 
Table 1. Total length and weight values in the male and female individuals of Neogobius melanostomus obtained from Lake Karaboğaz.

\begin{tabular}{|c|c|c|c|c|c|c|c|}
\hline & Male & Female & & \multicolumn{2}{|c|}{ Male } & \multicolumn{2}{|l|}{ Female } \\
\hline Age & $\begin{array}{l}\text { Total length } \\
\text { mean } \pm \text { SE } \\
(\text { min-max })\end{array}$ & $\begin{array}{c}\text { Total length } \\
\text { mean } \pm S E \\
(\text { min-max })\end{array}$ & p value & $\begin{array}{r}\text { Total weig } \\
\mathrm{S} \\
\left(\mathrm{min}^{-}\right.\end{array}$ & $\begin{array}{l}\text { t mean士 } \\
\text { ax) }\end{array}$ & $\begin{array}{c}\text { Total weight } \\
\text { mean } \pm \text { SE } \\
(\text { min-max })\end{array}$ & $\mathrm{p}$ value \\
\hline 1 & $\begin{array}{c}117.9 \pm 3.2 \\
(91-136)\end{array}$ & $\begin{array}{c}105.2 \pm 1.0 \\
(100-110)\end{array}$ & 0.003 & $30.5 \pm 2.4$ & $(12-37)$ & $\begin{array}{c}26.2 \pm 2.8 \\
(13-38)\end{array}$ & 0.258 \\
\hline II & $\begin{array}{l}135.2 \pm 1.1 \\
(115-175)\end{array}$ & $\begin{array}{c}124.0 \pm 1.2 \\
(111-143)\end{array}$ & 0.000 & $40.9 \pm 1.3$ & $(17-48)$ & $\begin{array}{c}32.5 \pm 0.9 \\
(19-81)\end{array}$ & 0.000 \\
\hline III & $\begin{array}{c}147.4 \pm 2.0 \\
(122-190)\end{array}$ & $\begin{array}{l}133.5 \pm 1.7 \\
(120-161)\end{array}$ & 0.000 & $56.5 \pm 2.4$ & $(28-70)$ & $\begin{array}{l}39.2 \pm 1.4 \\
(32-105)\end{array}$ & 0.000 \\
\hline IV & $\begin{array}{c}158.8 \pm 3.9 \\
(134-184)\end{array}$ & $\begin{array}{c}142.5 \pm 3.5 \\
(135-166)\end{array}$ & 0.008 & $73.2 \pm 6.4$ & $(38-82)$ & $\begin{array}{c}48.8 \pm 4.1 \\
(33-119)\end{array}$ & 0.011 \\
\hline
\end{tabular}

While the total length varied between $91-190 \mathrm{~mm}$ the weight varied between $12-119 \mathrm{~g}$. The mean total length and weight values of males were found to be higher compared to females for all age groups. According to the results of the ANOVA test conducted, a statistical difference was also found between the total lengths and weights of male and female individuals in all age groups.

The von Bertalanffy equation is $L_{t}=15.44[1-\mathrm{e}$ 0.47(t+5.98)] in female individuals and $L_{t}=19.96[1-\mathrm{e}$ $0.23(t+4.82)]$ in male individuals. The $L_{\infty}$ values are higher in male individuals (19.96) than female individuals (15.44). The growth performance index value, $\varnothing$, was calculated to be 2.045 in female individuals and 1.964 in male individuals.

The specific growth rate values slightly differ between female and male individuals. The GL values were found to be high in both male and female individuals in the transition from age 1 to age 2 , which is the first year of growth. However, the GW values were different between sexes but significant differences were not determined between the ages (Table 2).

Although the condition factor varies by months in both female and male individuals, increases and decreases correspond almost to the same months (Figure 2).

\section{Reproduction}

All samples were separated according to sex, and 102 females and 164 males were identified. While the F: M ratio was 0.62:1 in all individuals, the sex ratio by ages was different from the ideal sex ratio (1:1). The dominant age group was 2 and 3 (Table 3).

While the mean GSI values were higher in female individuals (8.25) than male individuals (1.12), the GSI changed in similar months in both male and female individuals. The highest GSI value was determined in April in female individuals (15.0) and in May in male individuals (3.3). The lowest GSI values were determined in female and male individuals in November (0.45) and September (0.07), respectively (Figure 3).

In all female individuals obtained from the study (102), the egg diameter was calculated and the change by months was determined. While the highest egg diameter was determined in May, the lowest value was determined in November (Figure

Table 2. $G L$ and $G W$ values of the male and female individuals of Neogobius melanostomus obtained from Lake Karaboğaz.

\begin{tabular}{ccccc}
\hline & \multicolumn{2}{c}{$\mathrm{GL}$} & \multicolumn{2}{c}{$\mathrm{GW}$} \\
\hline Age & Female & Male & Female & Male \\
\hline 1 & 16.6 & 13.7 & 21.5 & 29.3 \\
2 & 7.4 & 8.6 & 18.7 & 32.3 \\
3 & 6.5 & 7.4 & 21.9 & 25.9 \\
4 & - & - & - & - \\
\hline
\end{tabular}




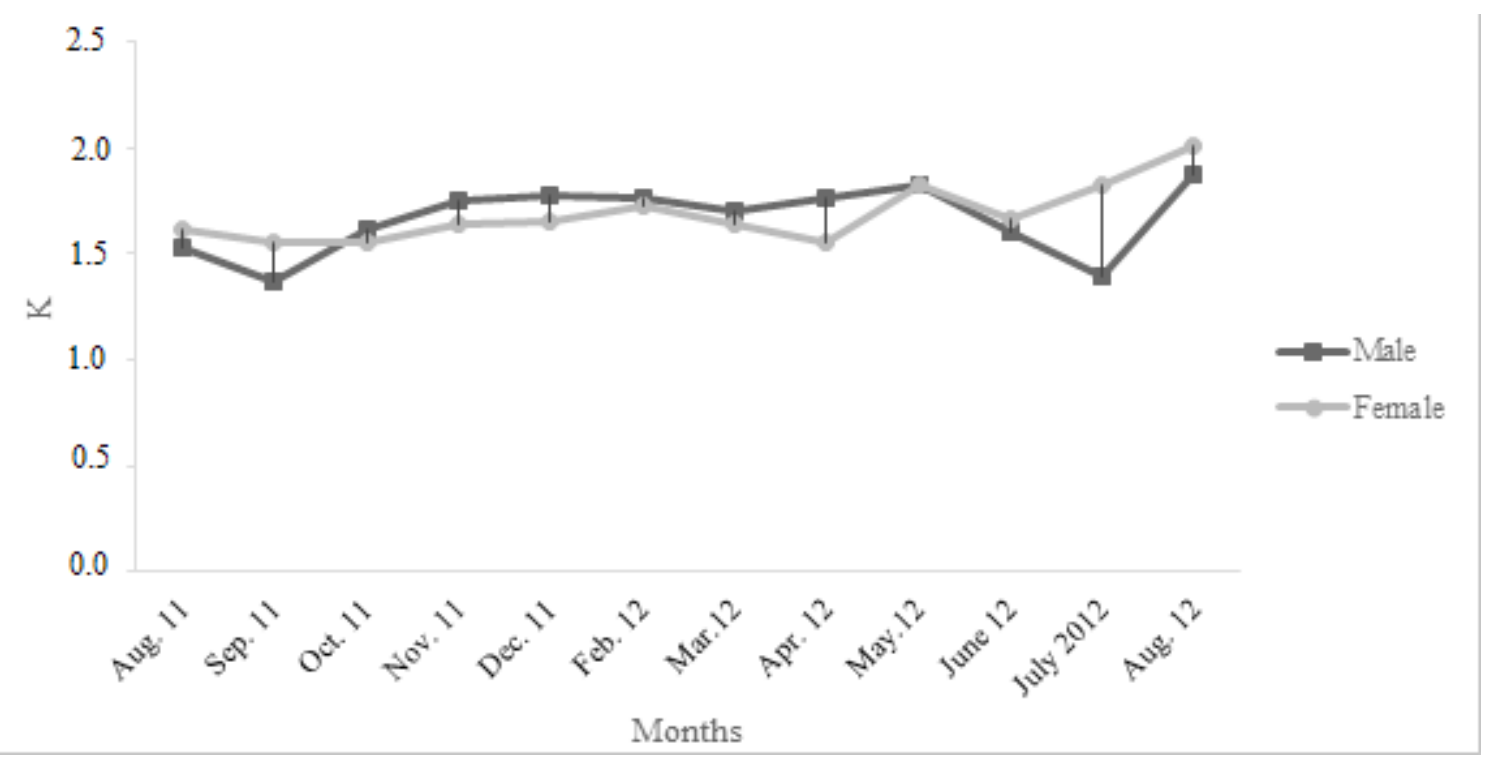

Figure 2. The change of the condition factor by months in N. melanostomus individuals obtained from Lake Karaboğaz.

Table 3. The change of the sex ratio by ages in $N$. melanostomus individuals obtained from Lake Karaboğaz.

\begin{tabular}{cccccc}
\hline & \multicolumn{2}{c}{ Male } & \multicolumn{2}{c}{ Female } & Sex Ratio \\
\hline Age & $\mathrm{N}$ & $\% \mathrm{~N}$ & $\mathrm{~N}$ & $\% \mathrm{~N}$ & F:M \\
\hline I & 13 & 56.5 & 10 & 43.5 & $0.8: 1$ \\
II & 91 & 68.9 & 41 & 31.1 & $0.5: 1$ \\
III & 44 & 51.8 & 41 & 48.2 & $0.9: 1$ \\
IV & 16 & 61.5 & 10 & 38.5 & $0.6: 1$ \\
\hline
\end{tabular}

4). The highest and lowest total fecundity were determined in age group III (2477) and age group IV, respectively. In addition, egg-bearing individuals were also determined in the age group I (2008) (Figure 5).

\section{DISCUSSION}

The growth and reproduction characteristics of $N$. melanostomus were examined in this study carried out in Lake Karaboğaz between August 2011 and August 2012. For this purpose, the age composition of $N$. melanostomus samples living in the lake was firstly determined. The age group III was found to be dominant $(48.2 \%)$ in female individuals and age group $\|$ (68.9\%) in male individuals (Table 3). Slastenenko (1955-1956) stated that $N$. melanostomus individuals usually reached up to 3-4 years of age and sometimes reached ages older than 4 years [1]. In this study, the age values obtained from Lake Karaboğaz were compared with the results of other studies carried out in order to reveal the growth characteristics of the species in question, and it was determined that the maximum age range reached by the $N$. melanostomus individuals living in different regions varied between 2-6 (Table 4 ). It is observed that the highest age group of $N$. melanostomus is determined in the Baltic Sea with high salinity and that the lowest age group is determined in rivers that are freshwater systems. Sokolowska and Fey (2011) stated that this situation was due to salinity and thus, the species in question showed a better development in salinated environments [33]. While the mean salinity of the Baltic Sea is 7\%o [35], the mean salinity of Lake Karaboğaz measured between August 2011 and August 2012 is $2.5 \%$ o. This result supports the relationship between salinity and the growth of $N$. melanostomus. The age values obtained from Lake Karaboğaz, that is located within the Black Sea-Caspian and Aral system, are compatible with the age values of other fish populations within the system in question. Consequently, it is observed that the age distribution of the $N$. melanostomus population living in Lake Karaboğaz is between the expected values in the systems where the species is naturally found. 


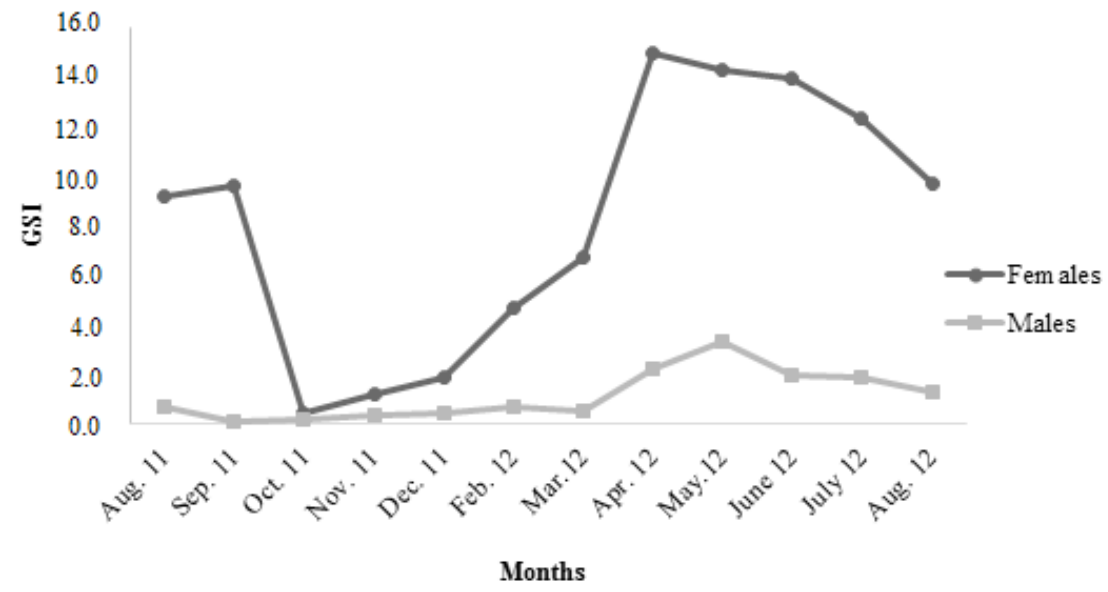

Figure 3. Monthly change of the mean GSI values of N. melanostomus obtained from Lake Karaboğaz.

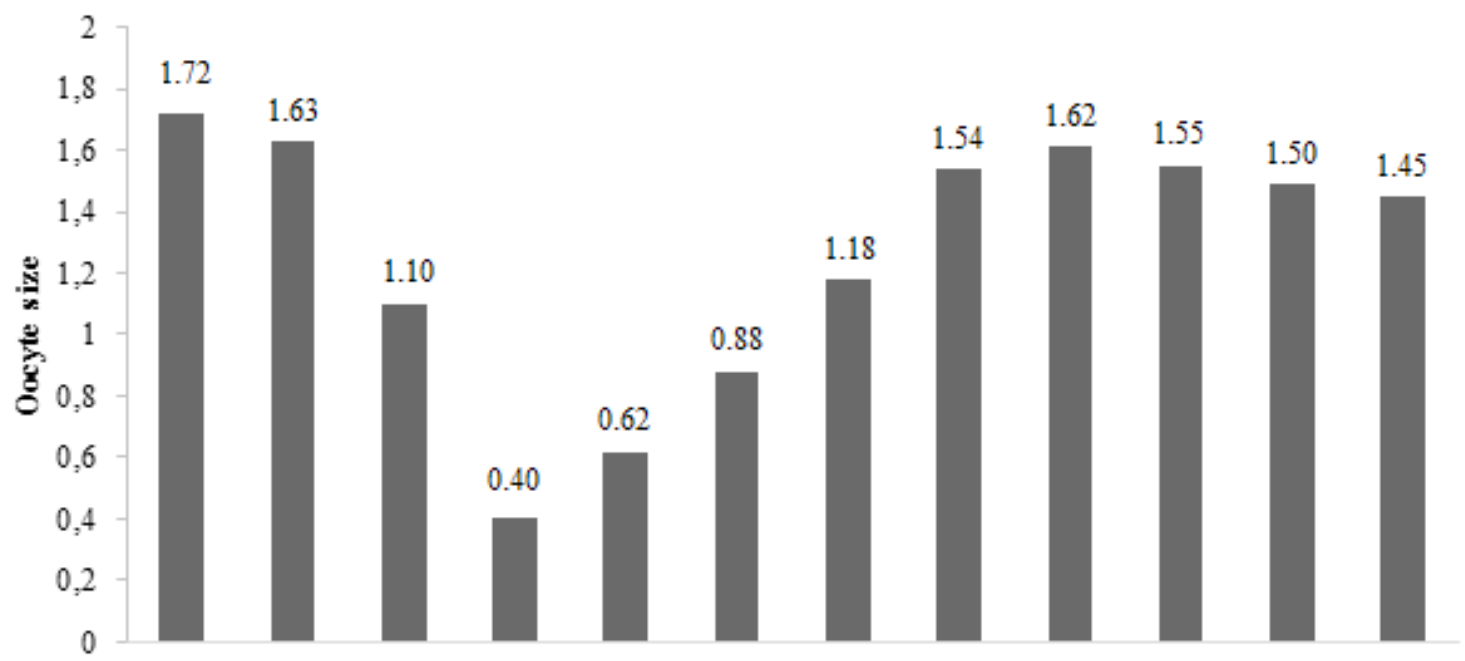

Aug. 11 Sep. 11 Oct. 11 Nov. 11 Dec. 11 Feb. 12 Mar. 12 Apr. 12 May. 12 June 12 July 12 Aug. 12

Months

Figure 4. Monthly change of the egg diameter in N. melanostomus individuals obtained from Lake Karaboğaz.

The mean length value of the population was determined to be $136 \mathrm{~mm}$. The mean total length values by age groups are $111 \mathrm{~mm}$ at age I, $132 \mathrm{~mm}$ at age II, $142 \mathrm{~mm}$ at age III and $159 \mathrm{~mm}$ at age IV, respectively. The total length values obtained in this study were compared with the total length values obtained from other studies carried out on the growth of the species in question (Table 5). Slastenenko (1955-1956) stated that the total length value of $N$. melanostomus individuals could reach up to $250 \mathrm{~mm}$ [32]. Upon examining Table 5, it is observed that the maximum total length value of $N$.

Figure 5. Monthly change of the total fecundity in N. melanostomus individuals obtained from Lake Karaboğaz. melanostomus is $250 \mathrm{~mm}$ (the Baltic Sea) and the minimum total length value is $98 \mathrm{~mm}$ (the Danube River, Yugoslavia). Regarding to total length values, 
Table 4. Age distribution of N. melanostomus populations living in different regions (as cited in Sokolowska and Fey, 2011).

\begin{tabular}{|c|c|c|c|}
\hline Study site & & $\begin{array}{l}\text { Maximum } \\
\text { Age }\end{array}$ & Researcher \\
\hline \multirow{7}{*}{ Baltic Sea } & Gda sk Bay & 6 & Sokolowska and Fey (2011) [33] \\
\hline & Gda sk Bay & 5 & Skóra \& Stolarski (1996) [37] \\
\hline & Gda sk Bay & $4 / 5$ & Wandzel $(2000,2003)[38,39]$ \\
\hline & Gda sk Bay & 4 & Sapota (2006) [11] \\
\hline & Gda sk Bay & 4 & Grygielewicz (1998) [40] \\
\hline & Gda sk Bay & $5 / 4$ & Mierzwicka (2000) [41] \\
\hline & Vistula Lagoon & 3 & Pliszka (2002) [42] \\
\hline Southern Europe & Danube River basin, Serbia and Yugoslavia & 3 & $\begin{array}{c}\text { Simonovi et al. }(1998,2001) \\
{[43,44]}\end{array}$ \\
\hline Eastern Europe & $\begin{array}{c}\text { Kuibyshev Reservoir, Central Volga, } \\
\text { Russia }\end{array}$ & 4 & $\begin{array}{c}\text { Shemonaev \& Kirilenko (2009) } \\
\text { [45] }\end{array}$ \\
\hline \multirow{2}{*}{$\begin{array}{l}\text { Great Laurentian } \\
\text { Lakes Basin }\end{array}$} & Upper Detroit River & 3 & Macinnis \& Corkum (2000) [14] \\
\hline & Lake Erie, Pennsylvania Tirbutary River & 4 & Phillips et al. (2003) [46] \\
\hline \multirow{11}{*}{$\begin{array}{l}\text { Black Sea-Caspian } \\
\text { and Aral system }\end{array}$} & Caspian Sea & 3 & Nikolskii (1963) [3] \\
\hline & The Sea of Azov & $3 / 4$ & Slastenenko (1955-1956) [1] \\
\hline & The Sea of Azov & 4 & Berg (1949) [47] \\
\hline & The Sea of Azov, Utluk Lagoon & 3 & Berg (1949) [47] \\
\hline & The Sea of Azov & 2 & Trifonov (1955) [48] \\
\hline & The Sea of Azov & 3 & Kostyuchenko (1961) [49] \\
\hline & The Sea of Azov & 3 & Apanasenko (1973) [50] \\
\hline & The Sea of Azov & 3 & Smirnov (1986) [51] \\
\hline & Black Sea, Crimea & 4 & Apanasenko (1973) [50] \\
\hline & Black Sea, Tiligul Lagoon & 4 & Apanasenko (1973) [50] \\
\hline & Karaboğaz Lagoon, Turkey & 4 & The Present Study \\
\hline
\end{tabular}

as well as in the age distribution, the highest and lowest values were respectively observed in marine systems with high salinity, and freshwater systems with low salinity. These data obtained are consistent with the opinion of Sokolowska and Fey (2011) that the growth of $N$. melanostomus is related to salinity [34].

According to the von Bertalanffy growth model, it was determined that male individuals grew faster (Female $L_{\infty}=15.44$, Male $\left.L_{\infty}=19.96\right)$. In all other studies carried out, it $w$ that the total length values of male individuals were higher than the total length values of female individuals in the same age group and that they grew faster. Nikolskii (1963) stated that the male individuals of the species in question grew faster than female individuals and could reach larger sizes [3].

When the $G L$ values of female and male individuals were examined separately, it was determined that both individuals had the highest OBA value at age I. When the $G L$ values of the sexes according to age groups were examined, it was determined that the $G L$ values of male individuals were higher compared to female individuals in all age groups ex- 
Table 5. Total length values of N. melanostomus individuals living in different regions (as cited in Sokolowska and Fey, 2011).

\begin{tabular}{|c|c|c|c|c|c|c|c|c|c|c|}
\hline \multirow{2}{*}{ Study site } & & \multirow{2}{*}{$\begin{array}{l}\text { Total } \\
\text { Length } \\
(\mathrm{mm}) \\
\end{array}$} & \multicolumn{7}{|c|}{ Age } & \multirow[b]{2}{*}{ Researcher } \\
\hline & & & 0 & 1 & 2 & 3 & 4 & 5 & 6 & \\
\hline \multirow{5}{*}{ Baltic Sea } & Gda sk Bay & 235 & - & - & 119 & 136 & 146 & 155 & 209 & $\begin{array}{c}\text { Sokolowska and Fey (2011) } \\
\text { [33] }\end{array}$ \\
\hline & Gda sk Bay & 246 & - & - & 152 & 182 & 212 & $x$ & - & $\begin{array}{c}\text { Skóra \& Stolarski (1996) } \\
\text { [37] }\end{array}$ \\
\hline & Gda sk Bay & 250 & - & 53 & 105 & 158 & 173 & - & - & Sapota (2006) [11] \\
\hline & Gda sk Bay & 214 & - & 65 & 118 & 152 & 176 & - & - & Mierzwicka (2000) [41] \\
\hline & Vistula Lagoon & 182 & - & 87 & 135 & 169 & - & - & - & Pliszka (2002) [42] \\
\hline \multirow{2}{*}{$\begin{array}{l}\text { Southern } \\
\text { Europe }\end{array}$} & $\begin{array}{l}\text { Danube River basin, } \\
\text { Serbia and Yugoslavia }\end{array}$ & 98 & 42 & 77 & 93 & $x$ & - & - & - & $\begin{array}{c}\text { Simonovi et al. }(1998, \\
\text { 2001) }[43,44]\end{array}$ \\
\hline & $\begin{array}{c}\text { Middle Danube River, } \\
\text { Slovakia }\end{array}$ & 153 & $\mathrm{x}$ & $\mathrm{x}$ & $\mathrm{x}$ & $x$ & $x$ & $x$ & $x$ & $\begin{array}{c}\text { L'avrin iková et al. (2005) } \\
\text { [52] }\end{array}$ \\
\hline \multirow{2}{*}{$\begin{array}{l}\text { Eastern } \\
\text { Europe }\end{array}$} & $\begin{array}{l}\text { Kuibyshev Reservoir, } \\
\text { Central Volga, Russia }\end{array}$ & 135 & $x$ & $x$ & $x$ & $x$ & $x$ & $x$ & $x$ & Tysplakov (1974) [53] \\
\hline & $\begin{array}{l}\text { Kuibyshev Reservoir, } \\
\text { Central Volga, Russia }\end{array}$ & 168 & 78 & 120 & 133 & 157 & $x$ & - & - & $\begin{array}{c}\text { Shemonaev \& Kirilenko } \\
\text { (2009) [45] }\end{array}$ \\
\hline \multirow{3}{*}{$\begin{array}{l}\text { Great } \\
\text { Laurentian } \\
\text { Lakes } \\
\text { Basin }\end{array}$} & St Clair River, Michigan & 118 & $x$ & $x$ & $x$ & $x$ & $x$ & $x$ & $x$ & Jude et al. (1992) [54] \\
\hline & Upper Detroit River & 124 & - & 63 & 76 & - & - & - & - & $\begin{array}{c}\text { Macinnis \& Corkum (2000) } \\
{[14]}\end{array}$ \\
\hline & $\begin{array}{c}\text { Lake Erie, } \\
\text { Pennsylvania Tirbutary } \\
\text { River }\end{array}$ & 112 & 44 & 68 & 80 & - & $x$ & - & - & Phillips et al. (2003) [46] \\
\hline \multirow{6}{*}{$\begin{array}{l}\text { Black Sea- } \\
\text { Caspian } \\
\text { and Aral } \\
\text { system }\end{array}$} & Caspian Sea & 190 & - & 69 & 88 & 111 & 138 & - & - & Nikolskii (1963) [3] \\
\hline & The Sea of Azov & 250 & - & 130 & - & - & 180 & - & - & Berg (1949) [47] \\
\hline & The Sea of Azov & 140 & - & 93 & 102 & - & - & - & - & Apanasenko (1973) [50] \\
\hline & Black Sea, Crimea & 150 & - & 54 & 88 & 104 & 116 & - & - & Apanasenko (1973) [50] \\
\hline & $\begin{array}{l}\text { Black Sea, Tiligul } \\
\text { Lagoon }\end{array}$ & 130 & - & 80 & 88 & - & - & - & - & Apanasenko (1973) [50] \\
\hline & $\begin{array}{c}\text { Karaboğaz Lagoon, } \\
\text { Turkey }\end{array}$ & 136 & - & 111 & 132 & 142 & 159 & - & - & The Present Study \\
\hline
\end{tabular}

cept the age group I. Wootton (1990) stated that the length increase value, which is high in the first years, reaches sexual maturity and slows down due to the fact that the large part of food and energy is separated between activities such as the development of the gonads and the formation of sex cells [29]. It is thought that the fact that the GL values of male individuals are higher compared to female individuals in all age groups except the age group I is due to the separation of energy between gonads along with the fact that female individuals reach sexual maturity. Indeed, as a result of this study carried out in Lake Karaboğaz, it was determined that the female individuals and male individuals of $N$. melanostomus reached sexual maturity in the age group I and in the age group II, respectively.
When the weight values were examined by sexes, it was determined that the lowest weight and the highest weight in female individuals were $12 \mathrm{~g}$ and $82 \mathrm{~g}$, respectively, and the lowest weight and the highest weight in male individuals were $13 \mathrm{~g}$ and $119 \mathrm{~g}$, respectively. Yankova et. al. (2011) stated that the mean weight value of $N$. melanostomus individuals sampled from the Black Sea coast of Bulgaria was $58.1 \mathrm{~g}$, the minimum weight value was $37.5 \mathrm{~g}$ and the maximum weight value was $113 \mathrm{~g}$ [34]. When these data are examined, it is observed that the weight values of $N$. melanostomus individuals living in Lake Karaboğaz are compatible with the populations living in other regions. Whether this difference determined between sexes in terms of weight was 
statistically significant was tested with ANOVA. The test results revealed that the mean weight difference between sexes was significant in all age groups. Slastenenko (1955-1956) stated that the weight values from the age I to the age II observed in female and male individuals of $N$. melanostomus population living in the Sea of Azov were $29 \mathrm{~g}, 41 \mathrm{~g}$ and $74 \mathrm{~g}$, respectively, in female individuals and $37 \mathrm{~g}, 71 \mathrm{~g}$ and $106 \mathrm{~g}$ in male individuals, respectively [32]. When these values are examined, it is observed that the weight values of male individuals are higher than the weight values of female individuals in all age groups.

The value of the condition factor $(K)$, which is calculated over both the length and weight parameters and reflects the growth characteristics of fish populations, gives information about the nutritional power or nutritional level of the environment in which the fish is present, and is a very important growth parameter that allows for the comparison of populations of the same species living in different localities. This value also allows for their comparison in different age and sex groups within the same population by seasons and even months. The mean $\mathrm{K}$ value of $266 \mathrm{~N}$. melanostomus samples caught from Lake Karaboğaz was calculated to be 1.64 .

In general, it was determined that the $\mathrm{K}$ value of male individuals was higher than the $K$ value of female individuals. It was found out that the highest $K$ value was 1.69 in age group II in female individuals and 1.79 in age group IV in male individuals. The lowest $K$ value was found in September in both females and males. Growth in fish varies depending on many factors such as the amount of nutrients in the water, competition with other fishes, where the fish reaches sexual maturity, age and size, and is unique to the species and the development phase of the species [3].

N. melanostomus has entered the inland waters of Europe and North America both by the ships' balancing water or migrating through the rivers although they are naturally found in the Sea of Azov, the Black Sea and the Sea of Marmara [20]. The growth values of $N$. melanostomus, that do not give much importance to salinity, temperature, food and the area where they live, obtained from Lake Karaboğaz were comparatively discussed with the populations living in other regions, and it was determined that the growth was slower than the expected values in natural fish populations.

When the sex ratio of $N$. melanostomus individuals obtained from Lake Karaboğaz is examined, it is observed that male individuals are dominant in the population. Nikolskii (1963) stated that the ratio between sexes is close to $1: 1$ in many species in healthy fish populations [3]. The fact that the sex ratio of $N$. melanostomus individuals living in Lake Karaboğaz is different from the expected value in natural fish populations is due to the fact that fishing is performed in the spawning area of the species to determine the reproduction characteristics of the species in question. Slastenenko (1955-1956) stated that male N. melanostomus individuals did not leave the nest to protect eggs until larvae were hatched, and female individuals plumbed the depths of the sea to feed as soon as they laid eggs [1].

It was determined that the female and male individuals in the $N$. melanostomus population living in Lake Karaboğaz started to reach sexual maturity from the ages I and II, respectively. Nikolskii (1961) stated that the female and male individuals of $N$. melanostomus reached sexual maturity at the ages of 2 and 3, respectively [20]. Macinnis and Corkum (2000) found that most of N. melanostomus female individuals living in the Detroit River reached sexual maturity at the age of I and in smaller sizes compared to the populations living in Europe [14]. Nikolskii (1963) indicated that the age of reaching sexual maturity was closely related to biotic and abiotic factors affecting the growth such as water temperature and the abundance of nutrients in the environment as well as the climatic and geographical characteristics of the area [3]. According to these data, it was observed that the age of reaching sexual maturity of $N$. melanostomus individuals caught in Lake Karaboğaz was in the expected age range.

The highest GSI value was determined in April in female individuals by 15.0 and in May in male individuals by 3.3. Macinnis and Corkum (2000) found the highest GIS value in female individuals of $N$. melanostomus living in the Detroit River to be 
9.0 [14]. The GSI value of the female individuals of N. melanosotomus living in Lake Karaboğaz is quite high compared to these values. It is thought that the difference in the GSI indexes of $N$. melanostomus individuals sampled from different habitats is due to the fact that they depend on many factors such as the amount and quality of the nutrition consumed in the development of gonads, amount of light and temperature.

The determination of the reproduction period using the GSI values in $N$. melanostomus species is more successful compared to the other species of the Gobiidae family [14]. When the GSI values of female and male individuals were examined by months, it was determined that the GIS value in both sexes decreased in September and October and reached the highest value in April-May. According to this result obtained, it was determined that the reproduction period of $N$. melanostomus started in April and ended in September. Charlebois et al. (1997) indicated that the reproduction period of $N$. melanostomus individuals usually started in March April and continued until September and that the reproduction period in different regions ended in June (Romania), July (the Aral Sea) or September (Varna) [20].

When the egg diameters of the female individuals of $N$. melanostomus living in Lake Karaboğaz were examined, it was determined that the highest value was in May (1.62) and the lowest value was in November (0.40) and that the egg diameter increased continuously in the months after November.

It was determined that the number of eggs of $N$. melanostomus individuals was between 1420-2477. It was found out that the number of eggs increased with age in the other age groups except for the age group IV. Although the small number of eggs in the age group IV is not an expected result, this result is thought to be due to the small number of individuals in the age group in question $(n=10)$. Slastenenko (1955-1956) stated that the number of eggs of $N$. melanostomus female individuals living in the Sea of Azov varied between 325-3323 while Macinnis and Corkum (2000) stated that the number of eggs of the population living in the Detroit River varied between 310-5210 [1,14]. Charlebois et. al. (1997) stated that the number of eggs of $N$. melanostomus individuals living in the European waters was between 200-9771, and the number of eggs in some individuals could reach up to 10.000 [20]. Corkum and Macinnis (2000) stated that the egg yield of N. melanostomus individuals was generally low but they achieved success along with the high hatching rate of eggs and the fact that males kept watching for the nest [14]. When these data were analyzed, it was observed that the egg yield results obtained from Lake Karaboğaz were compatible with the natural populations of $N$. melanostomus spawning at a water temperature of $9-26^{\circ} \mathrm{C}$.

In conclusion, it was determined in this study carried out in Lake Karaboğaz, which is a shallow lagoon lake, that the growth values of $N$. melanostomus were lower than the expected intervals in the environments where they were locally present. The growth values of the population of this species, living in Lake Karaboğaz are lower than sea basins and higher than freshwater basins. It is believed that the reason for this is due to the fact that the $N$. melanostomus origin is marine but it is a secondary fresh water species. The fact that the number of eggs was less than the expected values is due to the fact that the species is locally present in Lake Karaboğaz and does not exhibit an invasive characteristic in its environment. These results are important for understanding the biology of the species and the breeding of the species in habitats where they are invasive.

\section{ACKNOWLEDGEMENTS}

This work was supported by the TÜBITAK under Grant number $111 \mathrm{~T} 645$.

\section{References}

1. E. Slastenenko, Karadeniz havzasi baliklari (The fishes of the Black Sea Basin), Et ve Balik Kurumu Publishers, Istanbul, Turkey, 1955-1956.

2. P.J. Miller, Age, growth and reproduction of the rock goby, Gobius paganellus L., in the Isle of Man, J. Mar. Biol. Assoc., 41 (1961) 737-769.

3. G.V. Nikolskii, The ecology of fishes, Academic Press, London, 1963.

4. M.J. Wonham, J.T. Carlton, G.M. Ruiz, L.D. Smith, Fish and ship: relating dispersal frequency to success in biological invasions, Mar. Biol., 136 (2000) 1111-1121.

5. E. Leppäkoski, S. Gollasch, P. Gruszka, S. Olenin, V. Panov, The Baltic- a sea of invaders, Can. J. Fish. Aq. Sci., 59 (2002) 1175-1188.

6. M.R. Sapota, K.E. Skóra, Spread of alien (nonindigenous) fish species Neogobius melanostomus in the Gulf of Gdansk (South Baltic), Biol. Invasions, 7 (2004) 157-164. 
7. S.Z. Ehrenberg, S. Hansson, R. Elmgren, Sublittoral abundance and food consumption of Baltic Gobies, J. Fish Biol., 67 (2005) 1083-1093.

8. K. Ådjers, J. Andersson, M. Appelberg, R. Eschbaum, R. Fricke, A. Lappalainen, A. Minde, H. Ojaveer, W. Pelczarski, R. Repe ka, HELCOM, Assessment of Coastal Fish in the Baltic Sea, Balt. Sea Environ. Proc. No. 103 A 2006.

9. H. Ojaveer, The round goby Neogobius melanostomus is colonising the NE Baltic Sea, Aquat. Invasions, 1 (2006) 44-45.

10. F. Freyhof, Immigration and potential impacts of invasive freshwater fishes in Germany, Leibniz Institute of Freshwater Ecology and Inland Fisheries (IGB), Annual Report, Berlin, (2003) 51-58.

11. M.R. Sapota, NOBANIS-Invasive alien species fact sheet - Neogobius melanostomus, From: online database of the North European and Baltic Network on Invasive Alien Species - NOBANIS www.nobanis. org, 2006.

12. M. Steingraeber, A. Runstrom, P. Thiel, round goby (Neogobius melanostomus) distribution in the Illinois Waterway System of Metropolitan Chicago, Fish and Wildlife Service Report, Fishery Resource Office, Onalaska, 1996.

13. M.S. Kornis, M.J.V. Zanden, Forecasting the distribution of the invasive round goby (Neogobius melanostomus) in Winconsin Tributaries to Lake Michigan, Can. J. Fish. Aquatic. Sci., 67 (2010) 553562.

14. A.J. Macinnis, L.D. Corkum, Fecundity and reproductive season of the round goby Neogobius melanostomus in the Upper Detroit River, T. Am. Fish. Soc., 129 (2000) 136-144.

15. L.D. Corkum, M.R. Sapota, K.E. Skora, The round goby, Neogobius melanostomus, a fish invader on both sides of the Atlantic Ocean, Biol. Invasions, 6 (2004) 173-181.

16. C.W.G.Beek, The round goby Neogobius melanostomus first recorded in the Netherlands, Aquat. Invasions, 1 (2006) 42-43.

17. K. Molnár, Some remarks on parasitic infections of the invasive Neogobius spp. (Pisces) in the Hungarian Reaches of the Danube River, with a description of Goussia szekelyi sp. n. (Apicomplexa: Eimeriidae), J. Appl. Ichthyol., 22 (2006) 395-400.

18. E. V. Shemonaev, E.V. Kirilenko, Some features of biology of the round goby Neogobius melanostomus (Perciformes, Gobiidae) in waters of Kuibyshev Reservoir, Vop. Ikhtiologii, 49 (2009) 483-487.

19. V. Rakauskas, E. Bacevi ius, Ž. Ptys, L. Ložys, K. Arba iauskas, Expansion, feeding and parasites of the round goby, Neogobius melanostomus (Pallas, 1811) a recent invader in the Curonian Lagoon, Lithuania, Acta Zool. Lit., 18 (2008) 3.

20. P.M. Charlebois, J.E. Marsden, R. G. Goettel, PR. K. Wolfe, D. J. Jude, S. Rudnicka, The round goby, Neogobius melanostomus (Pallas): a review of European and North American Literature, IllinoisIndiana Sea Grant Program and Illinois Natural History Survey, INHS Special Publication No. 20, 1997.

21. C.R. Veitch, M.N. Clout (eds.), Turning the tide: the eradication of invasive species, IUCN SSC Invasive Species Specialist Group, IUCN, Gland, Switzerland and Cambridge, UK., 2002.
22. K.J. Willis, H.J.B. Birks, What is natural? The need for a long-term perspective in biodiversity conservation, Science, 314 (2006) 1261-1265.

23. A.S. Tarkan, Ö. Gaygusuz, H. Acıpınar, Ç. Gürsoy, M. Özuluğ, Length-weight relationship of fishes from the Marmara Region (NW-Turkey), J. Appl. Ichthyol., 22 (2006) 271-273.

24. S.A. Demirhan, M.F. Can, Lenght-weight relationship for seven fish species from the Southeastern Black Sea, J. Appl. Ichthyol., 23 (2007) 282-283.

25. K.F. Lagler, Freshwater fishery biology, W.M.C. Brown Company, lowa, 1966.

26. D. Crag-Hine, J.W. Jones, The growth of dace Leuciscus leuciscus (L.), roach Rutilus rutilus (L.) and chub Squalius cephalus (L.) in Willow Brook, Northamptonshire, J. Fish. Biol., 1 (1969) 59-82.

27. J.Ci Philipart, Age et croissance de chevaine Leuciscus cephalus (L.) dans L'Ourthe et la Berwine, Ann. Soc. R. Zool. Bel., 102 (1972) 47-82.

28. J.C. Thomas, Management of the white seabass (Cynoscion nobilis) in California waters, Courtesy of Scripps Institution of Oceanography Library, 1968.

29. R.J. Wootton, Ecology of Teleost Fishes, Chapman and Hall, London, 1990.

30. D. Pauly, J.L. Munro, Once moreon growth comparison in fish and invertebrates, Fishbyte, 2 (1984) 1-21.

31. C.B. Shreck, P.B. Moyle, Methods for fish biology, American Fisheries Society, Bethesda, Maryland, USA, 1990.

32. R.J. Strange, Field examination of fishes, American Fisheries Society, Bethesda, Maryland, USA, 1996.

33. E. Sokolowska, D.P. Fey, Age and growth of the round goby Neogobius melanostomus in the Gulf of Gdansk several years after invasion, is the Black Sea a new promised land?, J. Fish Biol., 78 (2001) 1993-2009.

34. M.J. Laamanen, L. Forsström, K. Sivonen, Diversity of Aphanizomenon flos-aquae (Cyanobacterium) populations along a Baltic Sea salinity gradient, Appl. Environ. Microbiol., 68 (2002) 5296-5303.

35. M. Yankova, D. Pavlov, V. Raykov, V. Minneva, G. Radu, Length-weight relationships of ten fish species from the Bulgarian Black Sea Waters, Turk. J. Zool., 35 (2011) 265-270.

36. A. Asghar, A. Saeedeh, P. Rahman, H.K. Bahram, Feeding strategies of three Neogobius species in the Gomishan Wetland of Iran, South-east Caspian Sea, Zool. Middle East, 56 (2012) 49-54.

37. K.E. Skóra, J. Stolarski, Neogobius melanostomus (Pallas 1811) a new immigrant species in Baltic Sea, In Proceeding of the Second International Estuary Symposium 1993, Vol. 1, Gdynia: Crangon Issue, 1996.

38. T. Wandzel, T., The fecundity and reproduction of round goby Neogobius melanostomus (Pallas, 1811) in the Puck Bay (Baltic Sea), Bull. Sea Fish. Inst. Gdynia,2 (2000) 43-51.

39. T. Wandzel, The Round Goby Neogobius melanostomus (Pallas, 1811)-New Component of Ichthyocenosis of Southern Baltic: A Role in Ecosystem and Fishery. Gdynia: Wydawnictwo Morskiego Instytutu Rybackiego, 2003.

40. M. Grygielewicz, Age and growth rate of round goby (Neogobius melanostomus) from the Gulf of Gda sk, MSc Thesis, University of Gdask, Gdynia, Poland, 1998. 
41. A. Mierzwicka, Morphology of otoliths, age and growth rate of round goby (Neogobius melanostomus) from the Gulf of Gda sk. MSc Thesis, University of Gda sk, Gdynia, Poland, 2000.

42. J.A. Pliszka, Morphology of otoliths, age and growth rate of round goby (Neogobius melanostomus) from the Vistula Lagoon. MSc Thesis, University of Gda sk, Gdynia, Poland, 2002.

43. P. Simonovi, B. Valkovi, M. Paunovi, Round goby Neogobius melanostomus, a new Ponto-Caspian element for Yugoslavia, Folia Zool., 47 (1998) 305-312.

44. P. Simonovi, M. Paunovi, S. Popovi, S., Morphology, feeding, and reproduction of the round goby, Neogobius melanostomus (Pallas), in the Danube River Basin, Yugoslavia, J. Great Lakes Res., 27 (2001) 281-289.

45. E.V. Shemonaev, E.V. Kirilenko, Some features of biology of the round goby Neogobius melanostomus (Perciformes, Gobiidae) in waters of Kuibyshev Reservoir, Vop. Ikhtiologii, 49 (2009) 483-487.

46. E.C. Phillips, M.E. Washek, A.W. Hertel, B.M. Niebel, The round goby (Neogobius melanostomus) in Pennsylvania tributary streams of Lake Erie, J. Great Lakes Res, 29 (2003) 34-40.

47. L.S. Berg, L. S., Neogobius melanostomus (Pallas) byczok kruglak. In Freshwater Fishes of the USSR and Adjacent Countries. Guide of the Fauna of USSR, Zoologicheskii Institut Academi Nauk USSR, Moscow, 1949.
48. G.P. Trifonov, On reproductive biology of gobies from the Azov Sea, Trudy Karadagskoi Biologicheskoi Stancji, 13 (1955) 5-46.

49. V.A. Kostyuchenko, Age and growth of the round goby N. melanostomus (Pallas) in the Azov Sea, Trudy Azovsko-Chernomorskovo Nauchnoissledovotelnovo Instituta Rybnovo Khoziajstva i Okeanografi, 19 (1961) 45-60.

50. M.N. Apanasenko, Age and size of round goby Neogobius melanostomus (Pallas) from different regions of the Azov and Black seas, Biol. Morya, 31 (1973) 98-106.

51. A.I. Smirnov, Ryby, In Fauna Ukrainy, Kijev: Naukova Dumka, 1986.

52. M.L. L'avrin iková, V. Ková, S. Katina, Ontogenic variability in external morphology of round goby Neogobius melanostomus from Middle Danube, Slovakia. J. Appl. Ichthyol., 21 (2005) 328-334.

53. E.P. Tsyplakov, Expansion of the ranges of some fishes in connection with hydraulic engineering works on the Volga and acclimatization operations, J. Ichthyol., 14 (1974) 343-351.

54. D.J. Jude, R.H. Reider, G.R. Smith, Establishment of Gobiidae in the Great Lakes Basin, Can. J. Fish. Aquat. Sci., 49 (1992) 416-421. 